\title{
Quantitative and Qualitative Studies on Enterobacteriaceae in Ground Beef
}

\author{
Abdelrahman H.; Meawad, A and Shaheen, $H$ \\ Faculty of veterinary Medicine-Food Hygiene Department-Suez Canal \\ University
}

\begin{abstract}
:
120 packages of ground beef (40 each of fresh, frozen and frozen with Soya bean) were examined for the incidence of Enterobacteriaceae, Salmonella and E. coli. The incidence of Enterobacteriaceae was $100 \%, 75 \%$ and $87 \%$ in fresh, frozen and frozen with Soya ground beef respectively; and the mean counts were $6.3 \times 10^{4} \mathrm{cfu} / \mathrm{g}, 1.4 \times 10^{2} \mathrm{cfu} / \mathrm{g}$ and $1.6 \times 10^{3} \mathrm{cfu} / \mathrm{g}$ respectively. $E$. coli, Klebsiella oxytoca, Serratia marcescens and Serratia liquefaiens could be isolated from fresh ground beef; Proteus vulgaries, E. coli and Enterobacter sakazakii was isolated from frozen ground beef, while in case of frozen ground beef with Soya bean Klebsiella oxytoca, Proteus vulgaries, Citrobacter freundii, E. coli and Pantoea a gglomerans was isolated. The incidence of $E$. coli was 60\%, 35\%, 48\% in fresh, frozen and frozen ground beef with Soya bean respectively. The incidence of Salmonella was 0\%, $10 \%, 15 \%$ in fresh, frozen and frozen ground beef with Soya bean respectively. E. coli strains were serologically identified into $20 \mathrm{O}$ typable strains and $37 \mathrm{O}$ - untypable strains. The 20 O-typable strains were identified as $\mathrm{O}_{86}, \mathrm{O}_{119}, \mathrm{O}_{158}, \mathrm{O}_{145}$ and $\mathrm{O}_{115}$.

Key words: Ground beef, Enterobacteriaceae, E. coli, Salmonella
\end{abstract}

\section{Introduction:}

Meat and meat products are considered as an ideal culture medium for growth of many organisms (Gracey, 1986). Contamination of raw meat is one of the main sources of foodborne illnesses (Bhandare et al, 2007; Podpecan et al, 2007). Changes in eating habits, mass catering, unsafe food storage conditions and poor hygiene practices are major contributing factors to food associated illnesses (Hedberg $\boldsymbol{e t}$ al,
1992). Ground beef is either pure ground beef with or without any additives or with Soya bean protein (EOS, 2005). Enterobacteriaceae group has an epidemiological interest and importance as some of them are pathogenic and may cause serious infections and/or food poisoning. It is the most challenging bacterial contaminant to raw and processed meat products worldwide. Salmonella, E. coli, Proteus, and Klebsiella species are the most predominant species in all 
food poisoning cases associated with some meat products. (Mercuri and Cox, 1979; Ternstro“m and Molin, 1987) Although more attention is generally paid to the pathogenic properties of particular genera of Enterobacteriaceae, some members of the family constitute an important spoilage group when conditions favour their growth (Stanbridge and Davies, 1998; Nychas et al, 2008). Foodborne pathogens are the leading causes of illness and death in developing countries costing billions of dollars in medical care, medical and social costs (Fratmico et al, 2005) A number of high-profile outbreaks of foodborne illnesses have been associated with meat products. Wider recognition of the importance of emerging pathogens such as $E$. coli O157:H7 have increased consumer and public health concerns about the possible contamination of such products, with such undesirable pathogens. Most people are aware of the existence of Escherichia coli in ground beef. It is a very common form of bacteria that causes people to get sick. The bacteria live in the intestines of both animals and humans, and can transfer easily between them when proper food preparation methods are not employed. It can cause problems with the functioning of the digestive system and can severely affect bowel movements (Witherspoon, 2011) E. coli can get into meat during processing. If the contaminated ground beef is cooked to a degree less than $71^{\circ} \mathrm{C}$, the bacteria can survive and cause several health problems and even death. It leads to a severe diarrhea in infants and travelers, minor discomfort to sever cholera like disease, as well as food poisoning manifestations among adults (Frazier and Westhoff 1988; Mackie and Mecartney, 1989). Salmonella is one of the most important pathogenic genera implicated in foodborne bacterial outbreaks and diseases (Gouws, Visser and Brözel, 1998). There are several transmission routes for Salmonellosis, but the majority of human infections are derived from the consumption of contaminated meat and meat products (Hernandez et al, 2005) (Chittick et al, 2006) .Therefore the aim of the present study was carried out to evaluate the load of Enterobacteriaceae and the incidence of $E$. coli and salmonella in ground beef.

\section{Materials and Methods:}

Collection of samples: A total of 120 packages of ground beef (40 each of fresh, frozen and frozen with Soya bean) were collected from different local retailers in Ismailia province.

Preparation of samples: All samples were prepared according to the technique recommended by APHA (2001). 25g from each sample were transferred under aseptic condition to a sterile polyethylene bag containing $225 \mathrm{~mL}$ 
of $0.1 \%$ sterile buffered peptone water. The content of the bag was then homogenized using stomacher (Lab. Blender 400, Seward Lab, London) to have a dilution of $10^{-1}$ then further serial dilutions were carried out till $10^{-7}$.

Determination of total Enterobacteriaceae count: were determined by the technique recommended by ISO (2004)

Identification of isolates: was carried out by using API-20E system

Isolation of $\boldsymbol{E}$. coli : was carried out according to the method recommended by ICMSF (1996).

Isolation of Salmonella: was carried out according to the method recommended by ISO (2002b).

Serological identification of $E$. coli and Salmonella was carried out at Animal Health Research institute in Ismailia province.

\section{Results and Discussion:}

Enterobacteriaceae are wide spread in the environment and taken as useful indicators of hygiene and post processing contamination of processed meat. Furthermore, their count can be taken as an indicator of possible enteric contamination in the absence of coliforms even in low number.

The results reported in table (1) revealed that the incidence of Enterobacteriaceae in fresh, frozen and frozen with soya ground beef samples was $100 \%, 75 \%$ and $87 \%$ respectively. Nearly similar results were obtained by Lindberg et al. (1998) and Ali et al. (2010). Such results of high incidence of Enterobacteriaceae in ground beef were attributed due to unhygienic handling during processing, storage and distribution. Also addition of certain additives to meat products may lead to marked increase in the bacterial population (Sharaf, 1999). The results recorded in table (2) showed the mean values of Enterobacteriaceae count in ground beef were $6.3 \times 10^{4} \pm 2.8 \times 10^{4} \mathrm{cfu} / \mathrm{g}$ for fresh ground beef, $1.4 \times 10^{2} \pm$ $3 \times 10 \mathrm{cfu} / \mathrm{g}$ for frozen ground beef and $1.6 \times 10^{3} \pm 4.15 \times 10 \mathrm{cfu} / \mathrm{g}$ for frozen ground beef with soya bean respectively.

The results were nearly similar to those reported by Lindberg et al (1998) also by Crowley et al. (2005) in case of packaged minced beef samples. While lower results were recorded by Gustavsson \& Borch (1993) and Murray et al (2001). However higher findings were obtained by Crowley et al. (2005) in case of fresh, unpackaged, ground beef samples.

The variation in the results between different authors may be due to the differences in manufacture practices, storage conditions, handling and the effectiveness of hygienic measures applied during production.

The frequency distribution of Enterobacteriaceae among the examined samples of fresh ground beef as given in table (3) revealed that E. coli , Klebsiella oxytoca, Serratia marcescens and Serratia liquefaiens were isolated at 
incidence of $12 \%, 50 \%, 25 \%$ and $13 \%$ respectively and that given in Table (4) revealed that Proteus vulgaries, E. coli and Enterobacter sakazakii were isolated at incidence of $52 \%, 24 \%$ and $24 \%$ respectively in frozen ground beef, while that given in table (5) revealed that Klebsiella oxytoca, Proteus vulgaries, Citrobacter freundii, E. coli and Pantoea agglomerans were isolated at incidence of $13 \%, 50 \%$, $12 \%, 13 \%$ and $12 \%$ respectively in frozen ground beef with soya bean The obtained results were nearly similar to those reported by Stiles and Ng (1981), Ali et al (2010) and Doulgeraki et al (2011).

Serratia liquefaciens was known to proliferate in refrigerated foods (Drosinos and Board, 1995), and is frequently found to predominate in ground beef. S. liquefaciens and other Serratia spp. are considered to be opportunistic pathogens but have as yet not been implicated in diarrheal diseases and could be isolated only from fresh ground beef. Citrobacter freundii has been involved in a case of severe gastroenteritis and meat food has been identified as a vehicle of transmission (Thurm and Gericke, 1994 and Tscha" pe et al, 1995)

Results given in table (6) revealed that the incidence of $E$. coli in fresh, frozen, and frozen with soya bean ground beef was $60 \%, 35 \%, 48 \%$ respectively.

These results were nearly similar to those obtained by Hassan (1986) and Hussein \& Bollinger
(2005).Lower results were reported by Doyle and Schaeni (1987), Mousa et al (1993), Blanco and Blanco (1996), Chapman et al (2000), Fantelli and Stephan (2001), Vernozy - Rozand et al (2002), Baran and Gulmez (2003), Zaho et al (2004), Cagney et al (2004), Crawely et al (2005), Dambrosio et al (2007) and Bernardez et al (2007) While higher results were reported by Geoff et al. (2008). This variation in the results was attributed to poor sanitation during ground beef processing. The presence of $E$. coli in meat and meat products is considered as an indicator of the presence of a fecal contamination in addition to the unhygienic conditions during preparation, handling and storage.

The results given in table (7) showed that the incidences of Salmonella in fresh, frozen and frozen with Soya bean ground beef were $0 \%, 10 \%$ and $15 \%$ respectively. The results obtained are nearly similar to those obtained by Khalafalla (1996), Little et al (1998), Jordan et al (2006), Little et al (2008), Cetinkaya et al (2008), Duggan et al (2012) and Ahmed \& Shimamato. (2014). While higher results were obtained by Mrema et al (2006). These variation may be attributed to the level of the hygienic procedure adopted during meat processing.

The results given in table (9) revealed that 57 strains of E. coli isolated from the examined ground 
beewere serologically identified into 20 O-typable strains and $37 \mathrm{O}-$ untypable strains. The 20 O-typable strains were identified in table (10) as EPEC with the following serotypes O86, O119 and O158

Table 1: Incidence of Enterobacteriaceae in examined ground beef samples

\begin{tabular}{|l|l|l|l|l|}
\hline \multirow{2}{*}{ Samples } & \multicolumn{2}{|l|}{ Positive } & \multicolumn{2}{l|}{ Negative } \\
\cline { 2 - 5 } & No. & $\%$ & No. & $\%$ \\
\hline Fresh & 40 & 100 & 0 & 0 \\
\hline Frozen & 30 & 75 & 10 & 25 \\
\hline Frozen with Soya & 35 & 87 & 5 & 13 \\
\hline Total & 105 & 87 & 15 & 13 \\
\hline
\end{tabular}

Table 2: Enterobacteriaceae count in examined ground beef samples.

\begin{tabular}{|l|l|l|l|l|}
\hline Samples & Min. & Max. & Mean & S.E. \\
\hline Fresh & $13 \times 10^{2}$ & $5 \times 10^{5}$ & $6.3 \times 10^{4}$ & $2.8 \times 10^{4}$ \\
\hline Frozen & $<10$ & $4 \times 10^{2}$ & $1.4 \times 10^{2}$ & $3 \times 10$ \\
\hline Frozen with Soya & $2 \times 10^{2}$ & $7 \times 10^{3}$ & $1.6 \times 10^{3}$ & $4.5 \times 10$ \\
\hline
\end{tabular}

Table 3: Frequency distribution of Enterobacteriaceae among the examined samples of fresh ground beef

\begin{tabular}{|l|l|l|}
\hline Enterobacteriaceae species & F. & $\%$ \\
\hline E. coli & 7 & 12 \\
\hline Klebsiella oxytoca & 30 & 50 \\
\hline Serattia marcescens & 15 & 25 \\
\hline Serattia liquefaciens & 8 & 13 \\
\hline Total & 60 & 100 \\
\hline
\end{tabular}

Table 4: Frequency distribution of Enterobacteriaceae among the examined samples of fresh ground beef

\begin{tabular}{|l|l|l|}
\hline Enterobacteriaceae species & F. & $\%$ \\
\hline Proteus vulgaries & 23 & 52 \\
\hline E. coli & 11 & 24 \\
\hline Enterobacter sakazakii & 11 & 24 \\
\hline Total & 45 & 100 \\
\hline
\end{tabular}


Table 5: Frequency distribution of Enterobacteriaceae among examined samples of frozen ground beef with Soya bean

\begin{tabular}{|l|l|l|}
\hline Enterobacteriaceae species & F. & $\mathbf{\%}$ \\
\hline Klebsiella oxytoca & 7 & 13 \\
\hline Proteus vulgaris & 26 & 50 \\
\hline citrobacter freundii & 6 & 12 \\
\hline E. coli & 7 & 13 \\
\hline Pantoea agglomerans & 6 & 12 \\
\hline Total & 52 & 100 \\
\hline
\end{tabular}

Table 6: Incidence of E. coli in examined ground beef samples

\begin{tabular}{|l|l|l|l|l|}
\hline \multirow{2}{*}{ Sample } & \multicolumn{2}{|l|}{ Positive } & \multicolumn{2}{l|}{ Negative } \\
\cline { 2 - 5 } & No & $\%$ & No & $\%$ \\
\hline Fresh & 24 & 60 & 16 & 40 \\
\hline Frozen & 14 & 35 & 26 & 65 \\
\hline Frozen with Soya & 19 & 48 & 21 & 52 \\
\hline Total & 57 & 48 & 63 & 52 \\
\hline
\end{tabular}

Table 7: Incidence of Salmonella examined ground beef samples

\begin{tabular}{|l|l|l|l|l|}
\hline \multirow{2}{*}{ Sample } & \multicolumn{2}{|l|}{ Positive } & \multicolumn{2}{l|}{ Negative } \\
\cline { 2 - 5 } & No & $\%$ & No & $\%$ \\
\hline Fresh & 0 & 0 & 40 & 100 \\
\hline Frozen & 4 & 10 & 36 & 90 \\
\hline Frozen with Soya & 6 & 15 & 34 & 85 \\
\hline Total & 10 & 8 & 110 & 92 \\
\hline
\end{tabular}

Table 8: Serotyping of Salmonella in the examined ground beef samples

\begin{tabular}{|l|l|l|l|}
\hline & Samples no. & Positive samples & $\%$ \\
\hline Salmonella & 120 & 10 & $8 \%$ \\
\hline Serotypes & Untypable & \multicolumn{3}{|l}{} \\
\hline
\end{tabular}

Table 9: Serological identification of E. coli isolates from the examined ground beef samples

\begin{tabular}{|l|l|l|}
\hline Positive samples & O-typable & O-untypable \\
\hline 57 & $20(35 \%)$ & $37(65 \%)$ \\
\hline
\end{tabular}


Table 10: Incidence of identified E. coli serotypes in the examined ground beef samples

\begin{tabular}{|c|c|c|c|}
\hline Strain character & Serotypes & No. & $\%$ \\
\hline EPEC & $\begin{array}{ll} & \text { O86 } \\
\text { O119 } & \\
\text { O158 } & \end{array}$ & $\begin{array}{l}2 \\
2 \\
2\end{array}$ & $\begin{array}{l}10 \% \\
10 \% \\
10 \%\end{array}$ \\
\hline EHEC & O145 & 4 & $20 \%$ \\
\hline ETEC & O115 & 10 & $50 \%$ \\
\hline Total & - & 20 & $100 \%$ \\
\hline
\end{tabular}

Conclusion

\section{Recommendations}

High

incidence and

Enterobacteriaceae in ground beef constitute a public health hazard and has an epidemiological interest and importance as some of them are pathogenic and may cause serious infections and/or food poisoning as Salmonella, Escherichia coli, Enterococci, Proteus, and Klebsiella species which are considered as true indicator of poor sanitation during production, post processing contamination and the extent of faecal contamination. However, the greatest application

Enterobacteriaceae is the assessment of the overall quality of a food and the hygiene conditions present during the food processing.

The presence of Klebsiella spp, Salmonella and Escherichia coli, encountered in the examined samples of ground beef is alarming and give a warning signal for the possible occurrence of food borne intoxication. The following suggestive measures and recommendations should be taken in considerations:

1- Routine microbiological examination should be adopted in meat product factories, butchers shops, groceries and other food rendering outlet with a consequent certificate of nil presence food born bacteria.

2- Hygienic awareness should be applied for personnel whom involved in handling and preparing of food at factories, home or restaurants avoid fecal contamination.

3-Demands for increased food hygiene surveillance and control, with the overall objective of safeguarding the consumer against poor quality and unsafe food stuffs were recommended.

4- Application of GMP and GHP during slaughtering, processing, storage and distribution of meat.

5- Effort must be done to define a standard limit for Enterobacteriaceae count in the Egyptian Standards (E.S) for ground beef. 
References:

Ahmed, A. M. and Shimamoto, T., (2014): Isolation and molecular characterization of Salmonella enterica, Escherichia coli $\mathrm{O} 157: \mathrm{H} 7$ and Shigella spp. from meat and dairy products in Egypt . International Journal of Food Microbiology, 168-169, 57-62.

Ali, N. H., Farooqui, A., Khan, A., Khan, A. Y. and Kazmi, S.U (2010): Microbial contamination of raw meat and its environment in retail shops in Karachi, Pakistan. J. Infect. Dev. Ctries. 4(6):382-388.

APHA (2001): American Public Health Association. Compendium of methods for the microbiological examination of food. $4^{\text {th }}$ ED., Washington D., USA.

Baran, F. and Gulmez, M. (2003): The occurrence of Escherichia coli O157:H7 in the Ground Beef and Chicken Drumsticks. Internet Journal of Food Safety, 2, 13-15.

Bernardez, M. I., Gonzalez, E. A. and Blanco, J. (2007): serotypes, virulence genes and intimin types of Shiga toxin (verocytotoxin) producing E. coli isolates from minced beef on Lugo(spain) from 1995 through 2003. J. BMC Microbiol. (7):13.

Bhandare, S.G., Sherikary, A.T., Paturkar, A.M., Waskar V.S., and Zende, R. J. (2007): A comparison of microbial contamination on sheep/goat carcasses in a modern Indian abattoir and traditional meat shops. Food Control, 18: 854-868.
Blanco, J. E. and Blanco, M. (1996): Detection of Enterohaeamorrhagic Escherichia coli $\mathrm{O} 157: \mathrm{H} 7$ in minced beef using immunomagnetic separation. Microbiol. 12(3): 385-94.

Cagney, C., Crowley, H., Duffy, G., Sheridan, J.J., O'Brien, S., Carney, E., Anderson, W., McDowell, D.A., Blair, I.S., Bishop, R.H. (2004: Prevalence and numbers of Escherichia coli O157: $\mathrm{H} 7$ in minced beef and beef burgers from butcher shops and supermarkets in the Republic of Ireland. Food Microbiol. 21, 203212.

Cetinkaya, F., Cibik, R., Soyutemiz, G. E., Ozakin, C., Kayali, R. and Levent, B. (2008): Shigella and Salmonella contamination in various foodstuffs in Turkey. Food Control 19, 10591063.

Chapman, P.A., Siddons, C.A., Cerda'n Malo, A.T. and Harkin, M.A. (2000: A one year study of Escherichia coli $\mathrm{O} 157$ in raw beef and lamb products. Epidemiol. Infect. 124, 207-213.

Chittick, P., Sulka, A., Tauxe, R. V., \& Fry, A. M. (2006): A summary of national reports of foodborne outbreaks of Salmonella Heidelberg infections in the United States: clues for disease prevention. Journal of Food Protection, 69, 1150-1153.

Crowley, H., Cagney, C., Sheridan, J.J., Anderson, W., McDowell, D.A., Blair, I.S., Bishop, I.S. and Duffy, G. (2005): 
Enterobacteriaceae in beef products from retail outlets in the Republic of Ireland and comparison of the presence and counts of E. coli O157:H7 in these products. J. Food Microbiology 22, 409-414.

Dambrosio, A.V., Lorusso, N.C., Quaglia, A. and Parisi, G. (2007): Escherichia coli $\mathrm{O} 157: \mathrm{H7}$ in 10and 25- gram ground beef samples with an evanescent- wave biosensor with silica and polystyrene waveguides. J. Food protect; 56 (4): 596-602.

Doulgeraki, A. I., Paramithiotis, S. and Nychas, G. J. E. (2011): Characterization of the Enterobacteriaceae community that developed during storage of minced beef under aerobic or modified atmosphere packaging conditions. Int. J. Food Microbiol. 145, 77-83.

Doyle M. P. and Schaeni, J. L. (1987): Isolation of E. coli O157:H7 from retail fresh meats and poultry. Appl. Environ. Microbiol., 53:2394- 2396.

Drosinos, E.H. and Board, R.G. (1995): Attributes of microbial associations of meat growing as xenic batch cultures in a meat juice at $48^{\circ} \mathrm{C}$. Int. J. Food Microbiol. 26, 279-293.

Duggan, S., Jordan, E., Gutierrez, M., Barrett, G., O'Brien, T., Hand, D., Kenny, K., Fanning, J., Leonard, N. and Egan, J. (2012): Salmonella in meats, water, fruit and vegetables as disclosed from testing undertaken by Food Business Operators in Ireland from
2005 to 2009. Irish Veterinary Journal, 65:17.

EOS (2005): Egyptian Standards, Minced Meat Mixed With Soybean Protein. E.S: 2097 - 2005, ICS: 67.120.10.

Fantelli, K. and Stephan, R. (2001): Prevalence and characteristics of Shigatoxinproducing Escherichia coli and Listeria monocytogenes strains isolated from minced meat in Switzerland. Int. J. Food Microbiol. 70, 63-69.

Fratmico, P.M., Bhunia, A.K. and Smith J.L. (2005): Foodborne Pathogens in Microbiology and Molecular Biology, Caister Academic Press, Wymondham, Norfolk, UK, pp: 273.

Frazier, W.C. and Westhoff, D.C.W.(1988): Food Microbiology. $4^{\text {th }}$ Edn., McGrawHill International Editions Food Science Series, pp: 401.

Geoff, H., Andrew, P., Michelle, I., Andress, K., Geoff, R. and John, S. (2008): Microbial profiles of carcasses and minced meat from kangaroos processed in south Australia. Inter. J. Food Microbiol. 123; (1-2): 88-92.

Gouws, P. A., Visser, M., and Bro“ zel, V. S. (1998): A polymerase chain reaction procedure for the detection of Salmonella sp. with 24 hours. Journal of Food Protection, 61, 1039-1042.

Gracey, J.F. (1986): Meat Hygiene. 8th Edn., The English 
long Book Sic. And Baillier, Tindall, London.

Gustavsson, P., Borch, E. (1993): Contamination of beef carcasses by psychrotrophic Pseudomonas and Enterobacteriaceae at different stages along the processing line. Int. J. Food Microbiol. 48 (4), 243-245.

Hassan, Kh. M. (1986): Microbial association in cool stored beef. M. V. Sc. Thesis, Fac. Vet. Med. Cairo Univ.

Hedberg, C.W., Levine, W.C., White, K.E., Carlson, R.H., Winsor, DK., Cameron, D.N., MacDonald, K.L. and Osterholm, M.T. (1992): An International Foodborne Outbreak of Shigellosis Associated With a Commercial Airline. JAMA 268: 3208-3212.

Hernandez, T., Sierra, A., Rodriguez-Alvarez, C., Torres, A., Arevalo, M.P., Calvo, M., et al (2005): Salmonella enterica serotypes isolated from imported frozen chicken meat in the Canary Islands. Journal of Food Protection, 68, 2702-2706.

Husseine, H.S. and Bollinger, L.M. (2005): prevalence of Shiga toxin-producing $E$. coli in beef cattle. J. Food Protect. 68 (10): 2228 .

ICMSF (1996): International Commission on Microbiological Specifications for Foods. Microorganisms in Foods. Intestinally pathogenic Escherichia coli. Blachie Academic and professional London.

ISO (2002b): International Organization for Standardization.
Horizontal method for the detection of Salmonella spp. ISO 6579:2002 (E), Geneva, Switzerland.

ISO (2004): International Organization for Standardization. Horizontal method for the detection and enumeration of Enterobacteriaceae - part 2: colony count method. ISO 21528- 2:2004, Geneva, Switzerland.

Jordan, E., Egan, J., Dullea, C., Ward, J., McGillicuddy, K., Murray, G., Murphy, A., Bradshaw, B., Leonard, N., Rafter, P. and McDowell, S. (2006): Salmonella surveillance in raw and cooked meat and meat products in the Republic of Ireland from 2002 to 2004 International Journal of Food Microbiology, 112, 66-70.

Khalafalla, F. A. (1996): Microbial evaluation of raw meats, products and non- meat ingrediants. BeniSuef, Vet. Med. Res., 6(2).

Lindberg, A.-M., Ljungh, A., Aherne, L.S., Molin, G. (1998): Enterobacteriaceae found in high numbers in fish, minced meat and pasteurised milk or cream and the presence of toxin encoding genes. Int. J. Food Microbiol. 39, 11-17.

Little, C.L., Monsey, H.A., Nichols, G.L. and de Louvois, J. (1998): The microbiological quality of ready-to-eat dried and fermented meat and meat products. Int. J. Environ. Health Res. 8, 277-284

Little, C.L., Richardson, J.F., Owen, R.J., de Pinna, E. and Threlfall E.J. (2008): Campylobacter and Salmonella in 
raw red meats in the United Kingdom:

Prevalence, characterization and antimicrobial resistance pattern, 2003-2005. Food Microbiology, 25, 538-543.

Mackie, K.J. and McCartney, J.G. (1989): Medical Microbiology. Vol. 1 and 2, 30th Edn., Churchill Living Stone, Edinburg London Melbourne and New York.

Mercuri, A.J. and Cox, N.A. (1979): Coliforms and Enterobacteriaceae isolated from selected foods. J. Food Prot., 42: 712.

Mousa, M., Awad, H., Yassein, N. and Gouda, H. (1993): Microbial quality of some meat product. Alex. Vet. Med. J. 41(3):59-62.

Mrema, N., Mpuchane, S. and Gashe, B.A. (2006): Prevalence of Salmonella in raw minced meat, raw fresh sausages and raw burger patties from retail outlets in Gaborone, Botswana. .Food Control, 17, 207-212.

Murray, K.A., Gilmour, A. and Madden, R.H. (2001): Microbiological quality of chilled beef carcasses in Northern Ireland: a baseline study. J. Food Prot. 64 (4), 498-502.

Nychas, G.J.E., Skandamis, P.N., Tassou, C.C. and Koutsoumanis, K.P. (2008): Meat spoilage during distribution. Meat Science 78, 7789.

Podpecan, B., Pengov, A., and Vadnjal, S., 2007. The source of contamination of ground meat for production of meat products with bacteria staphylococcus aureus. Slov Vet. Res., 44: 25-30.

Sharaf, S. H. (1999): Bacteriological studies on meat and meat products with special reference to Salmonella and Shigella serotypes. Ph.D. Thesis (Meat Hygiene), Fac. Vet. Med. Moshtohor, Zagazig University (Benha branch).

Stanbridge, L.H. and Davies, A.R. (1998): The Microbiology of Chill Stored Meat. In: Davies, A.R., Board, R.G. (Eds.), The microbiology of meat and poultry. Blackie Academic and Professional, London, pp. 174-219.

Stiles, M. E. and Ng., L. K. (1981):

Enterobacteriaceae Associated with Meats and MeatHandling. Appl. Environ. Microbiol. 41(4):867-872.

Ternstro“m, A. and Molin, G. (1987): Incidence of potential pathogens on raw pork, beef and chicken in Sweden, with special reference to Erysipelothrix rhusiopathiae. J. Food Protect. 50, 141-146.

Thurm, V. and Gericke, B. (1994): Identification of infant food as a vehicle in a nosocomial outbreak of Citrobacter freundii: epidemiological subtyping by allozyme, whole-cell protein and whole-cell protein and antibiotic resistance. J. Appl. Bacteriol. 76, 553-558.

Tscha“pe, H., Prager, R., Streckel, W., Fruth, A., Tietze, E. and Bohme, G. (1995): Verotoxinogenic Citrobacter 
freundii associated with severe of haemolytic uraemic syndrome in a nursery school: green butter as the infection source. Epidemiol. Infect. 114, 441-450.

Vernozy-Rozand, C., RayGueniot, S., Ragot, C., Bavai, C., Mazuy, C., Montet, M.P., Richard, Y., Bouvet, J. (2002): Prevalence of Escherichia coli O157:H7 in industrial minced beef. Lett. Appl. Microbiol. 35, 7-11.
Witherspoon, J. (2011): E. coli in ground beef. http://EzineArticles.com/?expert=Ja mes_Witherspoon

Zhao, T., Doyle, M. P., Fedorka, P. J., Zaho, P., and Ladely, Q. (2004): Research note: occurrence of Salmonella enterica serotype Typhimurium DT104A in retail ground beef. J. Food protect. 659 (2): 403.

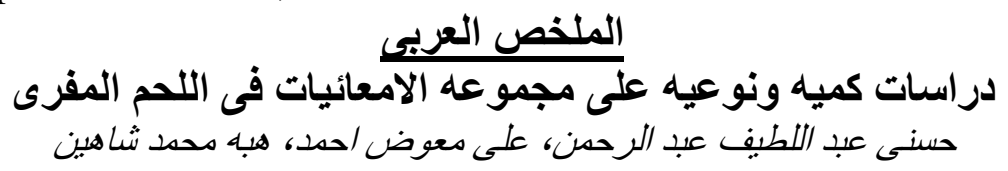

أجريت هذه الدراسه لاستبيان مدى تواجد مجموعه الامعائيات فى اللحم المفرى المتداول باسواق

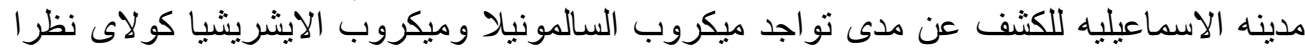

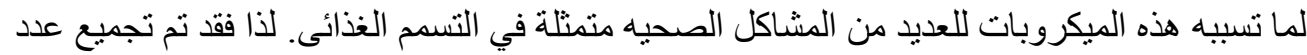

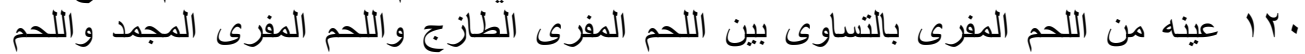

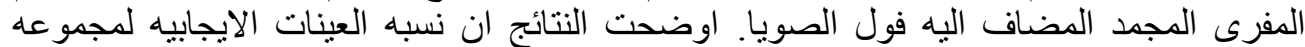

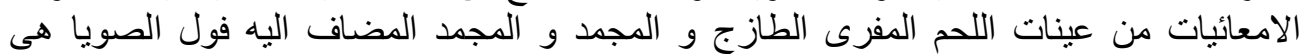

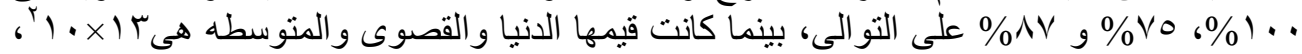

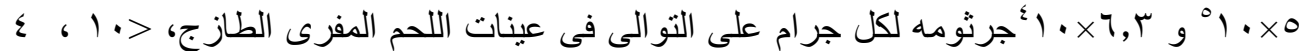

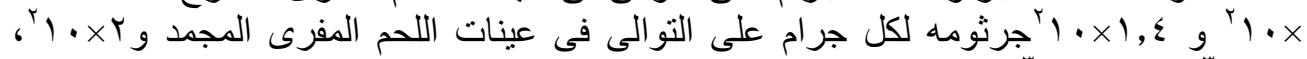

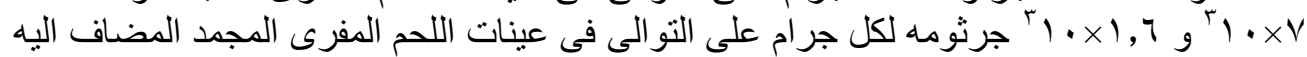
فول الصويا. هذا وتم تصنيف العترات المعزوله من عينات اللحم المفرى كالاتى: بالنسبه لعينات اللحم المفرى

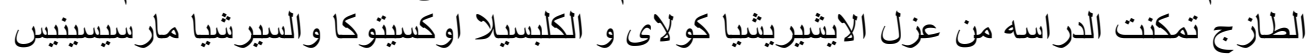

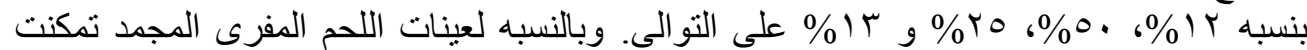

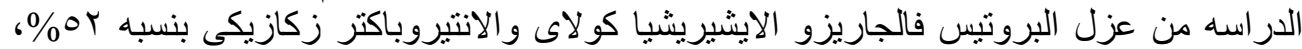

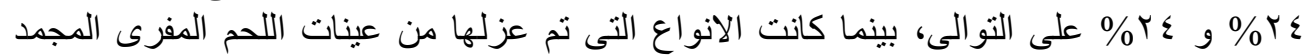

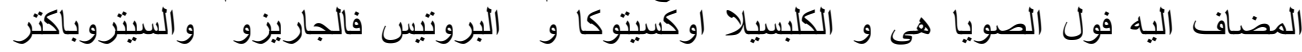

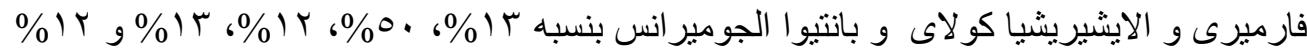

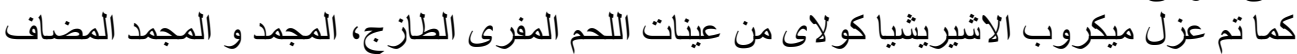

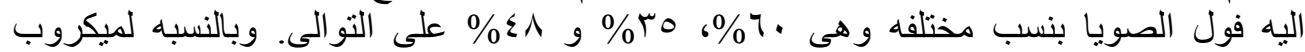

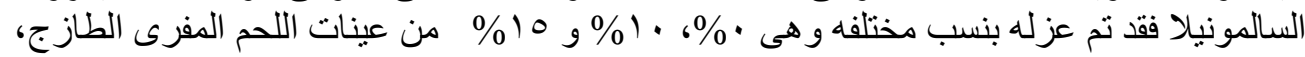

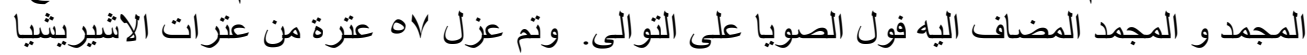

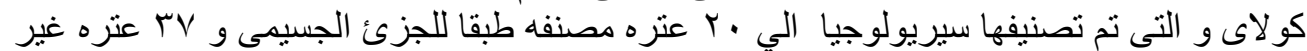

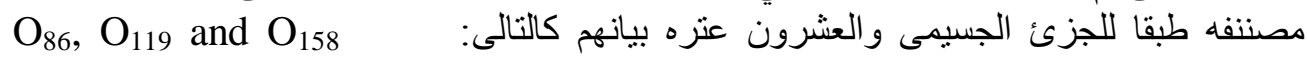
(EPEC); $\mathrm{O}_{145}$ (EHEC) and $\mathrm{O}_{115}$ (ETEC). 